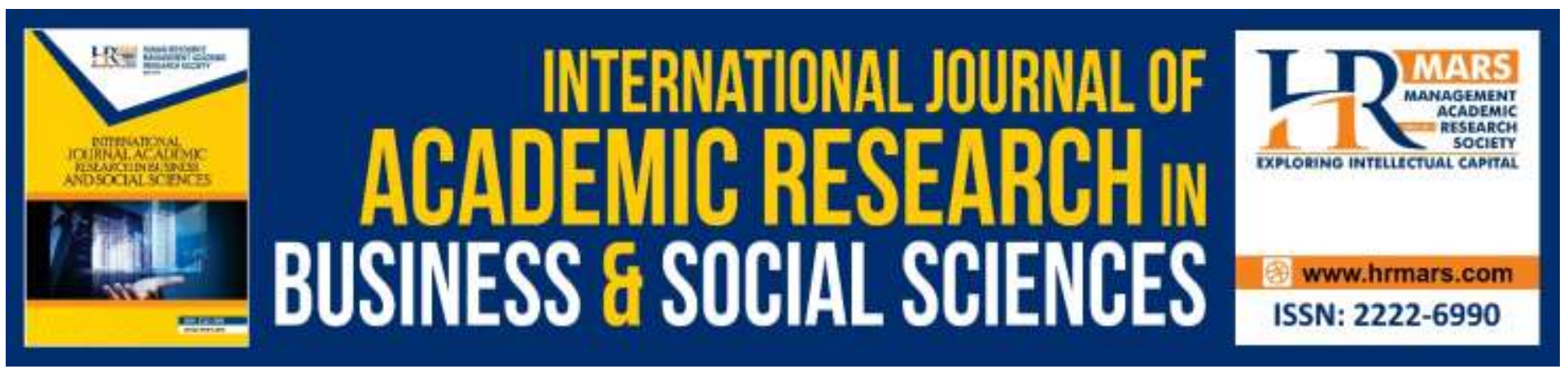

\title{
Measuring Future Sponsors' Perceived Value on Trust School Program
}

Siti Zaleha Sahak, Nooraini Mohamad Sheriff, Zaitun Udari, Nurfatin Ramlan, Muhammad Amir Amirul Mohamad

To Link this Article: http://dx.doi.org/10.6007/IJARBSS/v10-i4/7158

DOI:10.6007/IJARBSS/v10-i4/7158

Received: 02 March 2020, Revised: 29 March 2020, Accepted: 11 April 2020

Published Online: 29 April 2020

In-Text Citation: (Sahak et al., 2020)

To Cite this Article: Sahak, S. Z., Sheriff, N. M., Udari, Z., Ramlan, N., \& Mohamad, M. A. A. (2020). Measuring Future Sponsors' Perceived Value on Trust School Program. International Journal of Academic Research in Business and Social Sciences, 10(4), 600-608.

\section{Copyright: (C) 2020 The Author(s)}

Published by Human Resource Management Academic Research Society (www.hrmars.com)

This article is published under the Creative Commons Attribution (CC BY 4.0) license. Anyone may reproduce, distribute, translate and create derivative works of this article (for both commercial and non-commercial purposes), subject to full attribution to the original publication and authors. The full terms of this license may be seen

at: http://creativecommons.org/licences/by/4.0/legalcode

\section{Vol. 10, No. 4, 2020, Pg. 600 - 608}

Full Terms \& Conditions of access and use can be found at http://hrmars.com/index.php/pages/detail/publication-ethics 


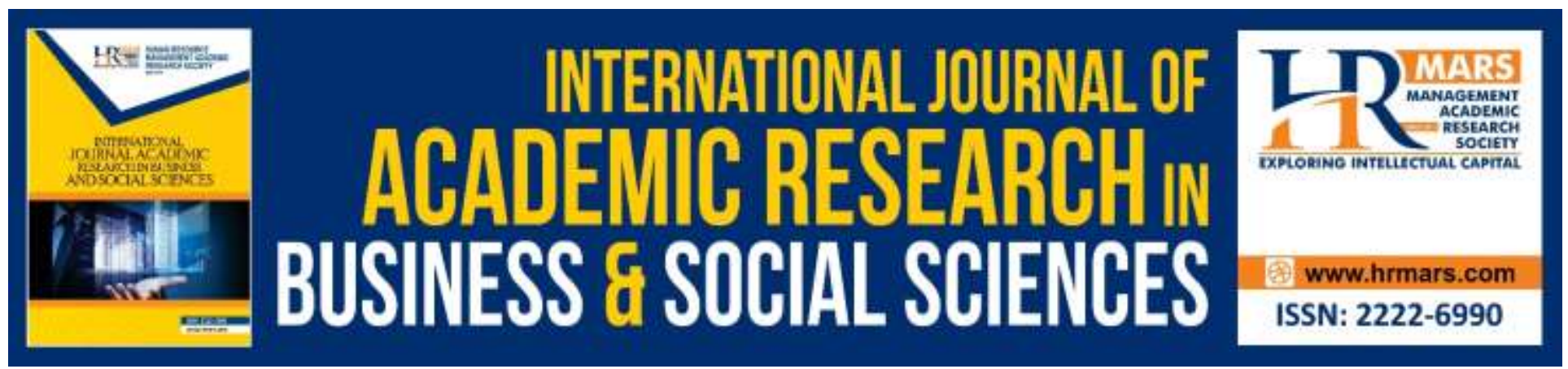

\title{
Measuring Future Sponsors' Perceived Value on Trust School Program
}

\author{
Siti Zaleha Sahak, Nooraini Mohamad Sheriff, Zaitun Udari, Nurfatin \\ Ramlan, Muhammad Amir Amirul Mohamad \\ Arshad Ayub Graduate Business School, Universiti Teknologi MARA, Malaysia
}

\begin{abstract}
This study aimed to measure the potential sponsors' perceived value on Trust School Program in Malaysia. The program utilized a private-public partnership concept. In getting more companies to sponsor the program, exploring their views on the benefits and costs of the sponsorship are vital. Following the established literature, the perceived value was operationalized as a multi-dimensional construct that comprised perceived quality, perceived price, perceived emotional, and perceived social value. A survey was carried out involving selected companies in Malaysia, and the PERVAL scale items were adapted to measure the four dimensions of perceived value. The findings of the descriptive analysis showed that perceived social value recorded the highest mean score and, this was followed by perceived quality. Nonetheless, overall, the average score of perceived value construct and its dimensions are considered at a moderate level. The managerial implications of the findings are highlighted.
\end{abstract}

Keywords: Perceived value, Sponsorship, Trust School, Malaysia

\section{Introduction}

Public-Private Partnership (PPP) plays a significant role in the economic and social development of a nation (Ram \& Irfan, 2019), and there is an increasing number of nations that embraced PPP in education (Hamilton, 2014). The Indian Ministry of Human Resource Development, for instance, has proposed PPP as an alternative to improve access to quality school education. The previous studies stated that the growth of the private school in India and the parents' preferences for the private schools over the government school, among others, was due to the poor performance of the public School (Kumari, 2016). PPP contracts are regarded as an innovative idea to attract private resources for improving education quality (Kumari, 2016) and social and public infrastructure (Ram \& Irfan, 2019; Hodge \& Greve, 2017).

In Canada, a study on the partnership between the Toronto District School Board and a condominium developer to redevelop a public high school in Toronto demonstrated how a process management orientation to the partnership could build trust between the partners and effectively share project 
INTERNATIONAL JOURNAL OF ACADEMIC RESEARCH IN BUSINESS AND SOCIAL SCIENCES Vol. 10, No. 4, April, 2020, E-ISSN: 2222-6990 @ 2020 HRMARS

risks (Robert \& Siematchyi, 2015). A study carried out in South Korea, examined a new form of PPP which involve a partnership between the government, business, and non-profit sectors. It is known as tripartite PPP (Hong \& Kim, 2018).

The governments of other countries like the United States, United Kingdom, and the Netherlands have long entered into the PPP arrangements in the education sector. The PPP is driven by two main reasons, which are their ability to produce better outcomes for students, and they offer more costeffective than the government directly delivering education services (Hamilton, 2014).

In Malaysia, the government, through the Ministry of Education, has also collaborated with the private sector in various education-related services. The practices suggested that PPP is not new to the country (Hamilton, 2014). In 2011, the Malaysia Ministry of Education (MOE) has initiated a Trust Schools Program. What is Trust School Program? The Trust School Program is a public-private partnership initiative between the Ministry of Education and Yayasan AMIR. The program, which is part of the Malaysia Education Blueprint 2013-2025, aims to improve the performance of students at national schools (MOE, 2019, Amir, 2018). Under this program, the schools remain under full government control and management, and the government provides the funding. The private-sector partner is taking part in education development by funding capacity building activities with school leaders and teachers. The funding is as philanthropic or social responsibility initiatives of the private sector and voluntary sector (Hamilton, 2014). The program represents a customizable model of education in developing holistic students with $21^{\text {st }}$-century learning capabilities. The lessons are conducted based on the students' learning abilities (The Star, 2019). Since its inception in 2011, the program has involved over 65,000 students in 83 schools across 12 states (The Star, 2019). The targeted sponsors of the program are corporations, non-profit organizations, alumni associations, and individual (Ministry of Education, 2019).

As per the Malaysia Education Blueprint 2013-2025, the government aims to create 500 trust schools by the year 2025 (Yayasan AMR, 2018; Hamilton, 2014). Nonetheless, getting sufficient funds to finance the transformation of 500 schools tends to be challenging as this depends on sponsorship or donation (Hamilton, 2014). Exploring the way, the companies perceive the cost and benefit of sponsoring the program may provide some inputs to the government in attracting and establishing a relationship with potential sponsors for the success of the program. Currently, most of the sponsorships come from the Government-Link -Companies (GLCs) (Amir, 2018).

Conceptually, Zeithaml (1988, p 14) defined perceived value as a 'consumer's overall assessment of the utility of a product (or service) based on perceptions of what is received and what is given." High customer value may result in strong customer loyalty and higher post-consumption intentions (Koller et al., 2011). This study was carried out to explore and to measure the potential sponsors' perceived value on the Trust Schools Program. The study utilized a multi-dimensional concept of perceived value as proposed in the Sweeney and Soutar's (2001) work. The four dimensions of perceived value are perceived quality, perceived price, perceived emotional, and perceived social value (Sweeney \& Soutar, 2001). 


\section{Review of Literature}

Sponsorship has increasingly gained popularity as a marketing communications vehicle (Cornwell et al., 2001). An empirical study shows that sponsorship plays a significant role in creating a corporate image, brand image, and brand awareness (Cornwell et al., 2001; Javalgi et al. 1994). According to Jahadi and Acikdilli (2009), sponsorship holds great potential to build corporate social responsibility (CSR) image given its reputation as a powerful means for "publicizing and highlighting a transparent, consistent and socially responsible corporate image" (Plewa at al., 2016, p.798). As highlighted by Keller (1993, p. 10), "anything that causes the consumer to 'experience' or be exposed to the brand has the potential to increase familiarity and awareness." Thus, sponsorship works as one of the platforms for companies to promote their relationship with customers (Plewa et al, 2016).

According to Hall (2016), sponsorship is a marketing tool that must be handled with prudence and professionalism. Most of the time it requires a huge amount of money or investment. Should the company get sponsorship right, it can work remarkably for the company. If not, consequently a lot of money may be wasted. Thus, evaluating and deciding which program or event to be sponsored are vital to any company.

Sweeney and Soutar (2001) categorized perceived functional value into two dimensions, namely, perceived quality and perceived price. Perceived quality is defined as the utility derived from perceived quality and expected performance of the product (Sweeney \& Soutar, 2001, p. 211). On the other hand, perceived price is defined as the utility derived from the product due to a reduction of its perceived short-term and long-term costs. This dimension is also known as the perceived value for money. The outcome of any sponsorship could be a bit intangible to be measured, particularly in short-term period. It is also argued that perhaps, this is the most difficult communications tool to measure the impact of (Hooley et., 2007). However, Cornwell et al. (2001) work indicated that in the case of sports event sponsorship, higher sponsorship leverage was related to a more significant perceived contribution to the financial value of the brand. In other words, sponsorship can create brand differentiation and adding financial value to the firm. The impact of sponsorship will be stronger when this activity is accompanied by effective advertising and other marketing communication strategies (Cornwell et al., 2001).

Perceived emotional value refers to the utility derived from the feelings or affective states that a product generates, and perceived social value represents the utility derived from the product's ability to enhance social self-concept (Sweeney \& Soutar, 2001, p. 212). According to Sheth et al. (1991), the sponsors will attempt to form a self-image by consuming the uniqueness of the program in obtaining social approval. Should the program have secure connections with the social groups, then the program will attain a high perceived social value. In the case of a trust school program, the social groups include the government, society, parents, students, teachers, and industry associations.

\section{Methodology}

This study utilized a survey method in gathering the primary data from the selected companies operated within Klang Valley areas. The survey instrument was distributed to the companies through 
face to face and an email. The companies selected were those yet to be the sponsors of the Trust School Program. The total number of responses obtained was 30.

Four dimensions measured the construct of perceived value, namely, perceived quality, perceived price, perceived emotional value, and perceived social value. The construct's measurement scale adapted in this study was PERVAL. The scale was developed by Sweeney and Soutar (2001). As documented in their work, the initial items of PERVAL were 107. Based on the rigorous data collection and analysis process, the scale was then purified to 85 items, followed by 63 items and further reduced to 24. The final PERVAL scale consists of 19 items. Six items (with two reverse score items) measure perceived quality, four items indicate measurement for the perceived price, five items measuring perceived emotional value, and four items measuring perceived social value. The scale was proven as reliable and valid in both pre-purchase and post-purchase situation. PERVAL can be used to measure consumers' perceived value on the product as well as on brand (Sweeney \& Soutar, 2001).

This study adapted 16 items of PERVAL (Sweeney \& Soutar, 2001) to measure the four perceived value dimensions. Two reverse score items for perceived quality and one item on perceived emotional value were excluded in this study as they seem not fit to the study context. All the items were measured using a five-point Likert Scale in which 1 represented "Strongly Disagree," and 5 represented "Strongly Agree." The recorded Cronbach alpha for the overall construct of perceived value of the 16 items was 0.93 .

\section{Analysis and Findings}

Table 1 provides the profiles of the companies which participated in this study. Fifty percent of the companies had more than 1000 employees. 16.7 percent had 501 to 1000 employees, and 26.7 percent had between 100 to 500 employees. 53.3 percent of the companies recorded annual revenue of more than RM 100 million. 20 percent indicated their annual revenue of RM 1,000,000 to RM50,000,000. 36.7 percent of the companies have been in the business between 10 to 50 years, and 30 percent of businesses were established in less than ten years. A vast majority of the participated companies $(90 \%)$ agreed that corporate social responsibility (CSR) is important to any company. 
INTERNATIONAL JOURNAL OF ACADEMIC RESEARCH IN BUSINESS AND SOCIAL SCIENCES Vol. 10, No. 4, April, 2020, E-ISSN: 2222-6990 @ 2020 HRMARS

Table 1: Company's Background

\begin{tabular}{|c|c|c|}
\hline Profile & $\mathbf{n}=\mathbf{3 0}$ & $\%$ \\
\hline \multicolumn{3}{|l|}{ Core business } \\
\hline Banking / Finance / Accounting & 4 & 13.3 \\
\hline Communication Carrier & 2 & 6.7 \\
\hline Airlines / Railway / Transportation & 2 & 6.7 \\
\hline Medical / Dental / Healthcare & 1 & 3.3 \\
\hline Construction / Architecture / Engineering & 5 & 16.7 \\
\hline Education & 1 & 3.3 \\
\hline Other & 15 & 50.0 \\
\hline \multicolumn{3}{|l|}{ Number of employees } \\
\hline Less than 100 & 2 & 6.7 \\
\hline $100-500$ & 8 & 26.7 \\
\hline $501-1,000$ & 5 & 16.7 \\
\hline More than 1,000 & 15 & 50.0 \\
\hline \multicolumn{3}{|l|}{ Annual revenue } \\
\hline Less than RM 1,000,000 & 2 & 6.7 \\
\hline RM 1,000,000 - RM50,000,000 & 6 & 20.0 \\
\hline RM 50,000,001 - RM100,000,000 & 6 & 20.0 \\
\hline More than RM 100,000,000 & 16 & 53.3 \\
\hline \multicolumn{3}{|l|}{ Business establishment } \\
\hline Less than 10 years & 9 & 30.0 \\
\hline 10 to 50 years & 11 & 36.7 \\
\hline 51 to 100 years & 7 & 23.3 \\
\hline More than 100 years & 3 & 10.0 \\
\hline \multicolumn{3}{|c|}{$\begin{array}{l}\text { Corporate Social Responsibility (CSR) is important to any } \\
\text { company }\end{array}$} \\
\hline Agree & 27 & 90.0 \\
\hline Disagree & 3 & 10.0 \\
\hline
\end{tabular}

The descriptive analysis of participants' responses on the items measurement of the four dimensions were carried out using SPSS software (version 22). As presented in Table 2, the findings of the analysis showed that the total mean score for the perceived value construct was 3.47 (SD = 0.51). The figure indicated a moderate level of the perceived value of the program among the participants. The average score of all 16 items of perceived value stood between 3.17 to 3.70. Two items with the highest mean score were 'The Trust Schools Program is what we really need' $(M=3.70, S D=0.84)$, and 'The Trust Schools Program would give its sponsor social approval' (M=3.70, SD =0.79). The first and latter belong to the measurement of perceived quality and perceived social value, respectively. By dimension, the perceived social value dimension recorded the highest mean score $(\mathrm{M}=3.61, \mathrm{SD}=$ $0.72)$. This was followed by the perceived quality dimension $(M=3.56 ; S D=0.77)$, perceived emotional value $(M=3.44 ; S D=0.74)$ and perceived value for money $(M=3.28 ; S D=0.64)$. 
INTERNATIONAL JOURNAL OF ACADEMIC RESEARCH IN BUSINESS AND SOCIAL SCIENCES Vol. 10, No. 4, April, 2020, E-ISSN: 2222-6990 @ 2020 HRMARS

Table 2: Descriptive statistics for perceived value construct and its dimensions

\begin{tabular}{lll}
\hline Items for measuring perceived quality & Mean & SD \\
\hline The Trust Schools Program has consistent quality. & 3.67 & 0.71 \\
The Trust Schools Program is what we really need & 3.70 & 0.84 \\
The Trust Schools Program would perform consistently. & 3.33 & 0.76 \\
The Trust Schools Program has an acceptable standard of quality. & 3.53 & 0.78 \\
Overall score & 3.56 & $\mathbf{0 . 7 7}$ \\
Items for measuring perceived price & Mean & SD \\
The Trust Schools Program is reasonably priced. & 3.13 & 0.68 \\
The Trust Schools Program offers value for money. & 3.30 & 0.60 \\
The Trust Schools Program would be economical. & 3.37 & 0.67 \\
The Trust Schools Program is a good product for the price. & 3.30 & 0.60 \\
Overall Score & 3.28 & $\mathbf{0 . 6 4}$ \\
Items for measuring perceived emotional value & Mean & SD \\
The Trust Schools Program would make us want to sponsor. & 3.17 & 0.70 \\
The Trust Schools Program would make us feel good. & 3.63 & 0.77 \\
The Trust Schools Program would give us pleasure. & 3.37 & 0.81 \\
The Trust Schools Program is one that we would enjoy. & 3.60 & 0.68 \\
Overall Score & 3.44 & $\mathbf{0 . 7 4}$ \\
Items for measuring perceived social value & Mean & SD \\
The Trust Schools Program would help us to feel acceptable. & 3.50 & 0.86 \\
The Trust Schools Program would give its sponsor social approval & 3.70 & 0.79 \\
The Trust Schools Program would make a good impression on other & 3.67 & 0.66 \\
people & & \\
The Trust Schools Program would improve the way we are perceived. & 3.57 & 0.57 \\
Overall Score & $\mathbf{3 . 6 1}$ & $\mathbf{0 . 7 2}$ \\
\hline Overall Score for Perceived Value Construct (total: 16 items) & $\mathbf{3 . 4 7}$ & $\mathbf{0 . 5 1}$ \\
\hline & & \\
\hline
\end{tabular}


INTERNATIONAL JOURNAL OF ACADEMIC RESEARCH IN BUSINESS AND SOCIAL SCIENCES

Vol. 10, No. 4, April, 2020, E-ISSN: 2222-6990 @ 2020 HRMARS

\section{Discussion}

The Trust Schools Program is featured in the Malaysia Education Blueprint 2013-2025 as instrumental catalytic support in operationalizing the transformation agenda (Yayasan Amir, 2018). The program is not a one-off program; instead, it is a continuous program in changing the culture in the School (The Star, 2019). The Ministry of Education is calling for more private organizations to participate in the program (The Star, 2018).

The result of the present study indicated that the potential sponsors' perceived value on the Trust School Program is positive. However, it was relatively moderate, with a mean score of 3.47 of 5.00. Thus, it is vital to the ministry and its related agencies to continuously and effectively promote the program to potential sponsors. According to Crimmins and Horn (1996), sponsoring needs articulation through advertising to be effective (Cornwell et al., 2001, p. 43). As stated by Yayasan Amir (2018), among the benefits of sponsorship offered through the program is media exposure and recognition as Trust Schools Sponsor. Linking this statement to the study's findings, it is critical for Yayasan AMIR and the government to effectively utilize the relevant media platforms in 'promoting' the name of the companies and their brands as Trust School Sponsor. This strategy may work hand in hand to create impactful sponsorship to both sides - the receiver and the giver. The media exposure offered by the program may also help the sponsors to develop their brand visibility among their stakeholders. Currently, according to Yayasan AMIR (2018), by sponsoring the program, the sponsors can participate in the knowledge exchange project and other events organized by Trust Schools.

The findings of the study also implied that the perceived performance of the program does matter to potential sponsors. According to Hamilton (2014), the success of an education PPP seems to be driven by the ways the government contracts with service providers, open tender transparency, robust contract KPIs, and active contract monitoring.

\section{Conclusion}

In conclusion, the two most important dimensions of the perceived value of the Trust School Program are, perceived social value and perceived quality. Thus, to generate the positive perceived value of the program among prospective sponsors, the responsible agencies may further emphasize the benefit offered by the program. Communicating the processes and procedures involve in the program and its operations may also help the potential sponsors to gain insights into the program quality.

Part of the limitations of this study is that the sample size employed is considered small. Further data collection is required with a more significant number of participants, and the use of a probability sampling technique may allow generalization of the results. Future studies may investigate the existing sponsors' perceived value of the program as the post-purchase stage, hence to help the government in sustaining the program. 
INTERNATIONAL JOURNAL OF ACADEMIC RESEARCH IN BUSINESS AND SOCIAL SCIENCES

Vol. 10, No. 4, April, 2020, E-ISSN: 2222-6990 @ 2020 HRMARS

\section{Acknowledgement}

This work was supported by funds received from the Arshad Ayub Graduate Business Research Grant Program, Universiti Teknologi MARA.

\section{Corresponding Author}

Siti Zaleha Sahak, Arshad Ayub Graduate Business School, Universiti Teknologi MARA, 40450 Shah Alam, Malaysia. Tel. + (60) 355444730, Email: siitiza344@uitm.edu.my

\section{References}

Cornwell, T. B., Roy, D. P., \& Steinard, E. A. (2001). Exploring managers' perceptions of the impact of sponsorship on brand equity. Journal of Advertising, 30(2), 41-51. http://dx.doi.org/10.1080/00913367.2001.10673636

Hall, R. (2016). Brilliant Marketing. $3^{\text {rd }}$ Edition, Pearson.

Hamilton, A. (2014). The Malaysian Trust School Model: It's good but is it sustainable? Policy Paper, Institute for Democracy and Economic Affairs. http://ideas.org.my/wpcontent/uploads/2017/03/PI-11-Trust-Schools.pdf

Hodge, G. A., \& Greve, C. (2017). On public-private partnership performance: A contemporary review. Public Works Management \& Policy, 22(1), 55-78. http://dx.doi.org/10.1177/1087724X16657830

Hooley, G., Piercy, N. F., Nicoulaud, B., \& Rudd, J. M. (2017). Marketing Strategy \& Competitive Positioning, $6^{\text {th }}$ Edition. Pearson.

Javalgi, R. G., Traylor, M. B., Gross, A. C., \& Lampman, E. (1994). Awareness of sponsorship and corporate image: An empirical investigation. Journal of advertising, 23(4), 47-58. http://dx.doi.org/10.1080/00913367.1943.10673458

Keller, K. L. (1993). Conceptualizing, measuring, and managing customer-based brand equity. Journal of Marketing, 57 (January), 1-22. http://dx.doi.org/10.1177/002224299305700101

Koller, M., Floh, A., \& Zauner, A. (2011). Further insights into perceived value and consumer loyalty: A "green" perspective. Psychology \& Marketing, 28(12), 1154-1176. https://doi.org/10.1002/mar.20432

Kumari, J. (2016). Public-private partnerships in education: An analysis with special reference to Indian school education system. International Journal of Educational Development, 47, 47-53. https://doi.org/10.1016/j.ijedudev.2015.11.017

Ministry of Education. (2019). General information on public-private partnership programs. https://www.moe.gov.my/penglibatan-sektor-swasta-menu/informasi-umum

Plewa, C., Carrillat, F. A., Mazodier, M., \& Quester, P. G. (2016). Which sport sponsorships most impact sponsor CSR image? European Journal of Marketing, 50(5/6), 796-815. https://doi.org/10.1108/ejm-02-2015-0078

Ram, S. A., \& Irfan, Z. B. (2019). A State Level Analysis of the Social Infrastructure: Public Private Partnership in Education and Health. Asian Journal of Education and Social Studies, 3(2), 1-28. https://doi.org/10.9734/ajess/2019/45502

Sheth, J. N., Newman, B. I., \& Gross, B. L. (1991). Why we buy what we buy: A theory of consumption values. Journal of Business Research, 22(2), 159-170. https://doi.org/10.1016/01482963(91)90050-8 
INTERNATIONAL JOURNAL OF ACADEMIC RESEARCH IN BUSINESS AND SOCIAL SCIENCES

Vol. 10, No. 4, April, 2020, E-ISSN: 2222-6990 @ 2020 HRMARS

Sweeney, J., \& Soutar, G. (2001). Consumer Perceived value: The development of a multiple item scale. Journal of Retailing, 77(2), 203-220. https://doi.org/10.1016/s0022-4359(01)00041-0

The Star Online. (2018). Organization's backing welcomed.

https://www.thestar.com.my/metro/metro-news/2018/08/06/organisations-backingwelcomed-ministry-all-for-private-sectors-to-support-trust-school-programme

The Star Online. (2019). More trust schools wanted.

https://www.thestar.com.my/news/education/2019/07/07/more-trust-schools-wanted

Amir, Y. (2018), Annual Progress Report 2018. $8^{\text {th }}$ Edition. https://a1870f1f-2892-4a90-a4bbc49f0dc78a1.filesusr.com/ugd/0ec405_d2c2bc4b3f4642eb8749216b1dc2530f.pdf

[Retrieved on 9 Dec. 2019]

Zeithaml, V. A. (1988). Consumer perceptions of price, quality, and value: a means-end model and synthesis of evidence. Journal of Marketing, 52(3), 2-22. https://doi.org/10.2307/1251446

Zeithaml, V. A., Berry, L. L., \& Parasuraman, A. (1996). The behavioral consequences of service quality. Journal of Marketing, 60(2), 31-46. https://doi.org/10.2307/1251929 